\title{
PREZENTACE ROZVAHY PODLE MEZINÁRODNÍCH STANDARDŮ IAS/IFRS
}

\section{Dagmar Čespivová}

\section{Klíčová slova:}

rozvaha, účetní závěrka, mezinárodní standardy účetního výkaznictví, zákon o účetnictví, harmonizace, aktivum

\section{Key words:}

balance sheet, statement of balances, international standards of the financial reporting, accounting law, harmonization, asset

\begin{abstract}
Abstrakt
Př́ispěvek se zabývá sestavováním a zveřejňováním rozvahy podle mezinárodních standardů účetního výkaznictví.Nejprve jsou uvedeny obecné informace o finančním účetnictví v kontextu mezinárodní účetní harmonizace.Dále příspěvek pojednává o základních účetních zásadách a předpokladech sestavení účetní závěrky. Cílem př́spěvku je analyzovat shody a neshody, které vyplývají při sestavování rozvahy podle mezinárodních účetních standardů a české účetní legislativy.
\end{abstract}

\begin{abstract}
This paper deals with completing and making public of a balance according to international standards of accounting audit.At first general information on financial accounting are described in context of international accounting harmonisation. The paper also describes basic accounting principles and presumptions to make balance of accounts. The goal of the paper is to analyse agreements and disagreements which result during completing of balance according to international accounting standards and czech accounting legislature.
\end{abstract}

\section{Úvod}

Nejvýznamnějším rysem současného vývoje světové ekonomiky je mezinárodní integrace, která nabývá globálních rozměrů. V současné době existují tř̌i významné linie mezinárodní účetní harmonizace. Jedná se o Mezinárodní standardy účetního výkaznictví IFRS ${ }^{1}$, účetní směrnice Evropské unie ${ }^{2}$ a národní účetní standardy USA - US GAAP ${ }^{3}$.

Účetní praxe se $\mathrm{v}$ jednotlivých zemích liší $\mathrm{z}$ mnoha důvodů, a to zejména $\mathrm{v}$ důsledku rozdílností ve vládách, ekonomických systémech, kultuře a tradicích. Přes mnohé odlišnosti však existují podstatné rysy společné účetnictví všech zemí. Na celém světě se ve finančním účetnictví používá bilanční princip a jeho vrcholovými výstupy jsou účetní výkazy, které zahrnují rozvahu, výsledovku, výkaz peněžních toků a výkaz o změnách ve vlastním kapitálu. Účetní výkazy jsou významným prostředkem komunikace mezi podnikem a externími uživateli, kterým poskytují užitečné informace.

\footnotetext{
${ }^{1}$ Komplex Mezinárodních standardů účetního výkaznictví IFRS obsahuje Mezinárodní účetní standardy IASInternational Accouning Standards a Mezinárodní standardy účetního výkaznictví IFRS international Financial Reporting Standards a jejich interpretace.

2 Zejména 4.,7. a 8.směrnice

${ }^{3}$ General Aceepted Accountig Principles
} 
Mezinárodní standardy účetního výkaznictví nejsou obecně platnou právní normou, přesto mohou být $\mathrm{v}$ menši či větší míře přijímány do národních či nadnárodních legislativ, $\mathrm{v}$ závislosti na typu právního prostředí. Celý komplex Mezinárodních standardů účetního výkaznictví je primárně určen pro kapitálové společnosti, jejichž cílem je dosahování zisku. V současné době se například povinně vyžaduje aplikace Mezinárodních standardů účetního výkaznictví upravených právem Evropského společenství (ES) u konsolidovaných účetních závěrek podniků, jejichž cenné papíry jsou obchodovány na burzách ve státech Evropské unie (EU).

V České republice účetní jednotky, které jsou obchodní společností a které jsou emitentem cenných papírů registrovaných na regulovaném trhu cenných papírů v členských státech Evropské unie, musí použít Mezinárodní standardy účetního výkaznictví upravené právem Evropského společenství i pro účtování a sestavení účetní závěrky.

Česká účetní legislativa ${ }^{4}$ je naproti tomu národním účetním systémem, který je založen na pravidlech a podléhá požadavkům předpisů Evropského společenství a $\mathrm{z}$ toho plynoucích závazků pro Českou republiku, tj. např. povinnosti zapracovat tato ustanovení do českého právního řádu. Zákon o účetnictví, který je hlavním pilířem české účetní legislativy, je základní, obecně platnou legislativní normou s celostátní platností.

Cílem příspěvku je podat obecný přehled o základních účetních zásadách a analyzovat shody a neshody, které vyplývají při sestavení rozvahy podle IFRS a ČÚL. Jednotlivé kapitoly jsou zpracovány metodou vysvětlujícího popisu, metodou analýzy a metodou komparace.

\section{Základní účetní zásady a předpoklady sestavení účetní závěrky}

Koncepční rámec pro přípravu a zveřejnění účetní závěrky řeší základní problémy účetního výkaznictví. Je velice důležitou úvodní částí Mezinárodních standardů účetního výkaznictví. Definice a zásady uvedené $\mathrm{v}$ Koncepčním rámci zásadním způsobem ovlivňují obsah informací zveřejňovaných $\mathrm{v}$ účetní závěrce. Jednotlivé standardy, které se zabývají konkrétními oblastmi a účetními problémy, z těchto definic vycházejí. Koncepční rámec není účetním standardem, a proto nedefinuje účetní postupy pro žádný konkrétní problém.

Koncepční rámec vymezuje uživatele účetní závěrky a jejich informační potřeby, cíl účetní závěrky, kvalitativní charakteristiky účetní závěrky, obsah a zpơsob rozpoznání základních prvků, které tvoří obsah účetní závěrky, koncepty oceňování, pojetí a uchování kapitálu.

Jedním z prvořadých úkolů účetních výkazů je poskytovat údaje pro potřeby finančního řízení vlastní firmy. Tento základní požadavek představuje členění aktiv a pasiv v rozvaze, obsah nákladů a výnosů a koncepce hospodářského výsledku ve výsledovce.

Účetní závěrka je určena především externím uživatelům, kde mezi nejvýznamnější skupiny patří současní a budoucí investoři, věřitelé, zaměstnanci, dodavatelé, odběratelé, konkurenční podniky, stát a orgány státní správy, finanční analytici, poradci, žurnalisté a nejširší veřejnost.

Uživatelé účetní závěrky požadují, aby účetní výkazy poskytovaly pravdivé informace o finanční pozici podniku, výkonnosti a efektivnosti jeho činnosti a o změnách ve finanční pozici.

\footnotetext{
${ }^{4}$ ČÚL
} 
Informace o výkonnosti a ziskovosti se využívají $\mathrm{k}$ odhadnutí možného vývoje struktury a velikosti zdrojů, které bude podnik využívat v budoucnu. Důležité jsou zejména informace o kolísaní výkonnosti. Tyto informace jsou obsaženy zejména ve výsledovce. Informace o finanční pozici, které jsou obsaženy v rozvaze dají odpověd' na otázky, jaké budou potřeby úvěrů a jak bude podnik úspěšný v jejich získávání.Informace o změnách ve finanční pozici umožňují uživateli zhodnotit schopnost podniku vytvářet peníze a kvantifikovat potřeby podniku při využití těchto peněžních toků. Podkladem pro tyto informace je výkaz peněžních toků.

Účetní závěrka by měla být pravdivým a věrným zobrazením finanční pozice, výkonnosti a změn ve finanční pozici podniku. Mezi požadované kvalitativní charakteristiky účetních výkazů patří srozumitelnost, významnost, spolehlivost a srovnatelnost.

Koncepční rámec definuje dva základní předpoklady, které musí být při sestavení účetní závěrky splněny. Jedná se o akruální bázi a předpoklad trvání podniku v budoucnosti.

Účetní závěrka sestavená na akruální bázi uznává výsledky transakcí a jiných nastalých skutečností v období, kdy k nim dochází tzn,. se kterými věcně a časově souvisí, nikoliv v okamžiku, kdy jsou realizovány s nimi související peněžní toky. Tento princip vyvolává potřebu časového rozlišení výdajů a př́ijmů, tvorbu dohadných položek a rezerv. Takto zjištěný hospodářský výsledek je vyčíslen jako rozdíl výnosů a nákladů a lépe odráží výkonnost podniku v daném účetním období než výsledek zjištěný na základě peněžní báze tedy jako rozdíl př́imů a výdajů.

Účetní závěrka vychází z předpokladu trvání podniku v budoucnosti, který znamená, že podnik neuvažuje o ukončení činnosti, ani není nucen likvidovat nebo podstatně zúžit rozsah své podnikatelské činnosti a v podnikání bude pokračovat v dohledné budoucnosti.

Vedení účetní jednotky musí při prrípravě účetní závěrky objektivně posoudit, zda je tento předpoklad zachován. Pokud má vedení účetní jednotky pochybnosti o dalším trvání podniku, musí tuto nejistotu zveřejnit. Podnik musí v účetní závěrce zveřejnit, že předpoklad trvání podniku není splněn a uvede důvody vedoucí k pravděpodobnému ukončení činnosti podniku.

Koncepční rámec není v ČÚL obsažen. Částečně jej nahrazuje český zákon ${ }^{5}$ o účetnictví, definující některé základní účetní postupy a požadavky, avšak mnoho koncepčních prvků, jako definice jednotlivých elementů finančních výkazů nebo rozbor účetních přístupů, v ČÚL chybí. Na rozdíl od zákona není Koncepční rámec standardem a v prípadě rozporu $\mathrm{s}$ jednotlivým standardem má přednost specifický standard.

Další zásadní rozdíl je ten, že Koncepční rámec se vztahuje primárně na účetní závěrky a vykazování, ${ }^{6}$ zatímco ČUUL se týká nejen účetních závěrek, ale také účetních záznamů a detailních aspektů účtování.

Koncepční rámec i zákon vymezují požadavky na kvalitativní charakteristiky účetní závěrky. Srozumitelnost je v ČÚL vyžadována pro účetní případy a záznamy, v IFRS pak pro celou účetní závěrku.

\footnotetext{
${ }^{5}$ Zákon o účetnictví č.563/1991 ve znění pozdějších předpisů

${ }^{6} \mathrm{i}$ když některé standardy řeší částečně i otázky spojené s účtováním
} 
Podle Koncepčního rámce nesmí informace obsahovat závažnou chybu a být zkreslené a uživatelé se na ně mohou spolehnout a dále musí splňovat princip převahy obsahu nad formou, nestrannosti, opatrnosti a úplnosti. Zákon klade na účetnictví další kvalitativní požadavky jako správnost, průkaznost, přehlednost a zajištění trvalosti účetních záznamů.

\section{Východiska sestavení rozvahy}

Základní požadavky na sestavení a obsah účetní závěrky v souladu s IFRS vytyčuje standard IAS $1^{7}$. Standard úzce navazuje na Koncepční rámec.

Cílem standardu IAS 1 je sjednocení požadavků na obsah účetní závěrky a zajištění srovnatelnosti účetní závěrky jak mezi podniky, tak srovnatelnosti obsahu účetních závěrek jednoho podniku v časové řadě ${ }^{8}$. Tento standard je aplikován na všechny obecné účetní závěrky zpracované a prezentované v souladu s IFRS ${ }^{9}$.

Standard IAS 1 obsahuje obecná ustanovení, ke kterým patří věrná prezentace a soulad účetní závěrky s IFRS. Účetní závěrka musí prezentovat věrně finanční pozici, finanční výkonnost a peněžní toky účetní jednotky.Věrná prezentace vyžaduje důvěryhodné zobrazení dopadů transakcí, jiných událostí a podmínek v souladu s definicemi a kritérii pro vykázání aktiv, závazků, výnosů a nákladů stanovených v Koncepčním rámci.

Součástí účetní závěrky je kompletní sada účetních výkazů, která obsahuje rozvahu, výsledovku, výkaz změn vlastního kapitálu, výkaz peněžních toků a komentár̆ obsahující shrnutí významných účetních pravidel s ostatními vysvětlujícími poznámkami.

Rozvaha je založená na bilancování majetku a zdrojů jeho krytí. Majetek podniku představuje přehled aktiv a zdroje financování tohoto majetku prezentuje vhodně uspořádaný přehled složek vlastního kapitálu, krátkodobých a dlouhodobých závazků podniku.

Při vykazování jednotlivých položek se účetní jednotka musí řídit zejména zásadou významnosti a jí podř́dit pravidla sumarizace aktiv do jednotlivých samostatně vykazovaných položek. Uvedený př́stup dává podnikům značnou volnost př́i přípravě vhodné struktury účetních výkazů a umožňuje sestavení rozvahy v souladu s konkrétními podmínkami účetní jednotky.

Standard IAS 1 navazuje na Koncepční rámec a v této oblasti je předmětem jeho úpravy řazení aktiv a pasiv v rozvaze, rozlišení krátkodobých a dlouhodobých aktiv a závazků, určení položek, které by měly být zveřejněny přímo v rozvaze a vymezení informací, které je třeba zveřejnit přímo rozvaze nebo $\mathrm{v}$ komentáŕi.

\footnotetext{
${ }^{7}$ Prezentace účetní závěrky

${ }^{8}$ Standard se nevztahuje na strukturu a obsah zkrácených mezitímních účetních závěrek v souladu s IAS 34 Mezitímní účetní výkaznictví. V rámci tohoto standardu se uvádí, že mezitímní účetní závěrka je sestavována bud' jako úplný soubor účetní závěrky, tak jak je prezentován v IAS 1, nebo jako zkrácená účetní závěrka. Pravidla pro sestavování mezitímní účetní závěrky ve zkráceném rozsahu stanovuje IAS 34.

${ }^{9}$ Dvořáková, D. Finančni účetnictví a výkaznictví podle mezinárodních standardů IAS/IFRS, str. 77
} 
Standard IAS 1 neurčuje jednotnou formu rozvahy. Jednotlivé komponenty účetní závěrky musí však být jasně identifikovány. Výrazně musí být označeny následující informace:

- název vykazující účetní jednotky nebo jiné způsoby identifikace,

- změny $\mathrm{v}$ těchto informacích oproti předchozímu rozvahovému dni,

- zda se jedná o konsolidovanou nebo individuální rozvahu,

- rozvahový den nebo období pokryté danou účetní závěrkou,

- měna prezentace ${ }^{10}$.

Standard IAS 1 nepředepisuje ani závazné pořadí položek, které mají účetní jednotky využívat. V praxi se ustálily dvě základní podoby formálního uspořádání rozvahy.Účetní jednotka může zvolit horizontální nebo vertikální formát rozvahy. Horizontální formát je označován jako $\mathrm{T}$ - forma ${ }^{11}$. Výkaz má podobu dvoustranné tabulky, aktiva jsou uváděna vlevo a pasiva vpravo ${ }^{12}$. Ve vertikální formě jsou položky výkazů uspořádány ve sloupci, u rozvahy jsou pasiva řazena za aktivy. Vertikální formát ${ }^{13}$ rozvahy preferuje hledisko likvidity.

Zatímco IFRS definuje obsáhlejší soubor povinných účetních výkazů, stanoví ČÚL striktnější požadavky na strukturu a rozvržení účetní závěrky než IFRS, který vyžaduje pouze minimální rozsah položek a nepředepisuje žádnou strukturu. Uspořádání účetní závěrky je předepsáno vyhláškou $^{14}$, v níž je zároveň stanoveno obsahové vymezení vybraných položek účetní závěrky. Požadované součásti účetní závěrky jsou obdobné; ČÚL však poskytuje větší volnost $\mathrm{v}$ tom smyslu, že výkaz peněžních toků a výkaz změn vlastního kapitálu jsou pouze volitelné.

\section{Klasifikace aktiv a závazků v rozvaze}

Účetní jednotka je ve své rozvaze povinna prezentovat krátkodobá a dlouhodobá aktiva a krátkodobé a dlouhodobé závazky jako samostatné klasifikace. Výjimkou jsou př́pady, kdy prezentace založená na likviditě poskytuje spolehlivější a relevantnější informace. V těchto výjimečných př́ípadech musí být všechna aktiva a závazky prezentovány obecně v pořadí podle likvidity ${ }^{15}$.

Standard IAS 1 definuje krátkodobost a dlouhodobost aktiva a závazku dvěma způsoby:

- prostřednictvím časového intervalu, kdy za krátkodobá aktiva jsou považována taková aktiva a závazky, které se přemění na peníze za dobu kratší než dvanáct měsíců ode dne sestavení rozvahy. Vypořádání nemusí mít nutně peněžní formu.

- $\quad$ vymezení vztahu aktiva nebo závazku k délce provozního cyklu. Krátkodobá aktiva a závazky jsou hrazeny $\mathrm{v}$ průběhu provozního cyklu. Tento způsob předpokládá, že lze vymezit délku provozního cyklu. Výhodou dané klasifikace je, že umožní respektovat individuální délku provozního cyklu v konkrétní účetní jednotce.

Standard definuje provozní cyklus podniku jako dobu mezi nákupem aktiv určených ke zpracování a jejich realizací $\mathrm{v}$ peněžních prostředcích nebo peněžních ekvivalentech.

\footnotetext{
${ }^{10}$ podle definice v IAS 21 Dopady změn měnových kurzů a úroveň zaokrouhlení použitou u prezentovaných částek účetní závěrky.

${ }^{11}$ Account format

${ }^{12}$ Horizontální formát je založen na bilanční rovnici, ve které se suma aktiv rovná sumě pasiv.

${ }^{13}$ Report format

${ }^{14}$ Vyhláška č.500/2002 Sb., kterou se provádí některá ustanovení zákona č.563/1991Sb., o účetnictví, ve znění pozdějších př̀edpisů.

${ }^{15}$ cit. IAS 1
} 
V př́padech, kdy nelze normální provozní cyklus podniku jednoznačně stanovit, se předpokládá, že činí dvanáct měsíců.

Standard také řeší krátkodobou a dlouhodobou klasifikaci finančních závazků, které mají být refinancovány nebo u kterých společnost porušuje závazky.

Standard IAS 1 vymezuje krátkodobé a dlouhodobé položky rozvahy následujícím způsobem. Mezi krátkodobá aktiva patř́i:

- aktiva, která se mají užít, spotřebovat nebo prodat v průběhu normálního provozního cyklu podniku (naprííklad výrobní zásoby a pohledávky z obchodního styku),

- aktiva držená zejména pro obchodní účely, tj., určená především k prodeji, a to nejdéle do 12 měsíců od data, k němuž se sestavuje rozvaha,

- peněžní prostředky a jejich ekvivalenty.

Dlouhodobá aktiva zahrnují ostatní položky aktiv.

Závazek je klasifikován jako krátkodobý, pokud splňuje některou z následujících podmínek:

- je součástí normálního provozního cyklu podniku,

- je držen primárně za účelem obchodování,

- bude uhrazen v následujících dvanácti měsících od rozvahového dne nebo účetní jednotka nemá právo bezpodmínečně právo odložit splatnost závazku na dobu delší než dvanáct měsíců.

IFRS i ČÚL vyžadují rozlišovat dlouhodobá a krátkodobá aktiva. Zatímco IFRS použivá koncept provozního cyklu podniku, drží se ČÚL pouze dvanáctiměsíčního kritéria. Klasifikační kriteria dle IFRS jsou mnohem robustnější a řeší specifické situace (např. refinancování, porušování závazků), které nejsou v ČÚL upraveny.ČÚL nevyžaduje rozlišovat mezi krátkodobými a dlouhodobými položkami časového rozlišení a rezerv.

Následující tabulka uvádí přehled položek, které minimálně musí účetní jednotka na základě požadavků IAS 1 povinně zveřejnit v nekonsolidované rozvaze.

Tabulka č. 1: Položky zveřejňované př́mo v rozvaze

\begin{tabular}{|l|l|}
\hline AKTIVA & PASIVA \\
\hline Pozemky, budovy a zařízení & Emitovaný kapitál a rezervní fondy \\
\hline Investice do nemovitostí & Menšinový podíl \\
\hline Nehmotná aktiva & Rezervy \\
\hline Investice oceňované ekvivalenční metodou & Odložené daňové závazky \\
\hline Odložené daňové pohledávky & $\begin{array}{l}\text { Finanční závazky ( nezahrnuté v jiných } \\
\text { položkách) }\end{array}$ \\
\hline $\begin{array}{l}\text { Finanční aktiva ( nezahrnutá do jiných } \\
\text { vyjmenovaných položek) }\end{array}$ & Závazky z titulu běžných daní \\
\hline Pohledávky z titulu běžných daní & Obchodní a jiné závazky \\
\hline Biologická aktiva & $\begin{array}{l}\text { Závazky, které jsou součśstí celků určených } \mathrm{k} \\
\text { prodeji }\end{array}$ \\
\hline Aktiva držená k prodeji & \\
\hline Zásoby & \\
\hline Obchodní a jiné pohledávky & \\
\hline Peníze a peněžní ekvivalenty &
\end{tabular}

Pramen: DVOŘÁKOVÁ, D., Finančni účetnictvi a výkaznictví podle mezinárodních standardi̊ IAS/IFRS, vlastní zpracování 
Účetní jednotka je povinna zveřejnit v rozvaze nebo v komentáři další podrobnější strukturu skupin aktiv a pasiv, jejíž zveřejnění požadují IFRS, které se zabývají jednotlivými oblastmi. Zveřejnění se může u jednotlivých položek lišit ${ }^{16}$.

Tabulka č. 2: Položky zveřejňované př́ímo v rozvaze nebo v komentáři

1. Pro každou kategorii základního kapitálu: počet autorizovaných akcií

počet akcií vydaných a plně splacených a dále

vydaných, ale plně nesplacených

nominální hodnotu akcie nebo to, že akcie nemají

nominální hodnotu

porovnání počtu akcií v oběhu na počátku a na

konci vykazovaného období

práva, přednostní práva a omezení přiřazená $\mathrm{k}$

dané kategorii včetně omezení výplaty

dividend a splacení kapitálu

vlastní akcie v držení účetní jednotky nebo v

držení jejích dceřiných společností nebo

přidružených podniků

akcie vyhrazené $\mathrm{k}$ vydání na základě opcí a smluv

o prodeji akcií včetně termínů a částek

2. Popis povahy a účelu jednotlivých fondů $v$

rámci vlastního kapitálu

Pramen: KRUPOVÁ, L., VAŠEK, L., ČERNÝ, M., IAS/IFRS Mezinárodní standardy účetního výkaznictví, vlastní zpracování

\section{Požadavky na rozvahu podle Evropské unie}

V probíhajících procesech integrace zemí EU existovala a stále je značná rozdílnost legislativní úpravy účetních výkazi̊, která se stávala vážnou překážkou, nebot' neumožňovala srovnatelnost vykazovaných informací. Další překážkou byl rozdílný prrístup vedení účetnictví. V současné době existuje tzv.anglosaský přistup, ten je charakteristický tím, že vlastní účtování není regulováno pouze vládními institucemi, ale projevuje se zde i vliv účetních a daňových specialistů. Opačný př́stup je kontinentální. Metody účtování jsou primárně usměrňovány zákony, navíc celý účetní systém má silnou vazbu na daňový systém. Český účetní systém vychází z kontinentálního př́stupu.

\footnotetext{
${ }^{16}$ (a) položky pozemků, budov a zařízení jsou rozděleny do tříd v souladu s IAS 16 Pozemky, budovy a zařízení (b) pohledávky jsou rozděleny na částky pohledávek za odběrateli, pohledávky za spřízněnými stranami, zálohové platby a ostatní částky,

(c) zásoby jsou členěny v souladu s IAS 2 Zásoby do skupin jako je zboží, výrobní zásoby, materiál, nedokončená výroba a hotové výrobky,

(d) rezervy jsou členěny na rezervy na zaměstnanecké požitky a další položky; a

(e) vlastní kapitál a rezervní fondy jsou členěny do různých tříd - např́íklad splacený kapitál, emisní ážio a rezervní fondy.
} 
To byl rozhodující argument pro vypracování typových vzorů účetních výkazů vymezeného okruhu kapitálových společností. Závazné pokyny pro členské země v oblasti účetnictví byly vydávány formou tzv.směrnic nebo direktiv. Účetnictví se týká tzv. 4. direktiva, 7. direktiva a 8. direktiva, které tvoří kodex účetní legislativy Evropské unie. Čtvrtá direktiva ${ }^{17}$ vydaná 25. července 1978 se zaměřila na harmonizaci účetních výkazů a jejím přijetím byl učiněn kompromis mezi dvěma rozdílnými pojetími regulace účetnictví v rámci EU.

Direktiva uvádí dva vzory rozvahy, jedná se o vertikální a horizontální formát rozvahy. Členské státy EU mohou vyžadovat sestavení rozvahy bud' podle jednoho ze dvou vzorů nebo podniky se mohou rozhodnout samy, který formát rozvahy zvolí.

Oba formáty rozvahy umožňují:

- znázornit funkční skladbu majetku a jeho zřetelné rozlišení na dlouhodobá a krátkodobá aktiva

- umožnit učinit si názor na dlouhodobou finanční stabilitu podniku, tzn. rozlišovat pohledávky a závazky podle zůstatkové doby jejich splatnosti ( do 1 roku a nad 1 rok)

- podat informace o vlastním kapitálu.

Tabulka č. 3 : Horizontální schéma rozvahy EU

\begin{tabular}{|c|c|c|c|}
\hline \multicolumn{2}{|l|}{ Aktiva } & ROZVAHA & Pasiva \\
\hline Položka & \multirow[t]{7}{*}{$K \check{c}$} & Položka & \multirow[t]{7}{*}{$K \check{c}$} \\
\hline $\begin{array}{l}\text { A. Pohledávky za } \\
\text { upsaným, } \\
\text { nesplaceným } \\
\text { kapitálem }\end{array}$ & & A. Vlastní kapitál & \\
\hline B. Zahajovací výdaje & & B. Rezervy & \\
\hline $\begin{array}{l}\text { C. Dlouhodobá } \\
\text { aktiva }\end{array}$ & & C. Závazky & \\
\hline D. Oběžná aktiva & & D. Přechodná pasiva & \\
\hline E. Přechodná aktiva & & E Zisk & \\
\hline \multirow[t]{2}{*}{ F. Ztráta } & & & \\
\hline & & Součet pasiv & \\
\hline
\end{tabular}

Pramen: KOVANICOVÁ, D., Finančni účetnictví - světový koncept IFRS/IAS, vlastní zpracování

\footnotetext{
17 Čtvrtá směrnice Rady 78/660/EHS ze dne 25. července 1978, o ročních účetních závěrkách určitých forem společností.
} 
Tabulka č. 4: Vertikální schéma rozvahy EU

\begin{tabular}{|l|l|}
\hline Položka & Ǩ̌ \\
\hline $\begin{array}{l}\text { A. pohledávky za upsaným, dosud } \\
\text { nesplaceným kapitálem }\end{array}$ & \\
\hline B. Zahajovací výdaje & \\
\hline C. Dlouhodobá aktiva & \\
\hline D. Oběžná aktiva & \\
\hline E. Přechodná aktiva & \\
\hline $\begin{array}{l}\text { F. Závazky krátkodobé: částky splatné do 1 } \\
\text { roku }\end{array}$ & \\
\hline $\begin{array}{l}\text { G.Čistá aktiva po odečtení krátkodobých } \\
\text { závazků (D+E) -(F+K) = G }\end{array}$ & \\
\hline $\begin{array}{l}\text { H. Součet aktiv po odečtení krátkodobých } \\
\text { závazků }\end{array}$ & \\
\hline I. Závazky dlouhodobé & \\
\hline J. Rezervy & \\
\hline K.Přechodná pasiva & \\
\hline L.Vlastní kapitál & \\
\hline
\end{tabular}

Pramen: KOVANICOVÁ, D., Finanční účetnictví - světový koncept IFRS/IAS, vlastní zpracování

V České republice je tradičně využívána horizontální forma rozvahy, jejíž struktura je poměrně podrobně stanovena vyhláškou.

Tabulka č. 5: Porovnání ustanovení čtvrté direktivy a české právní úpravy u vybraných položek

\begin{tabular}{|c|c|c|}
\hline Položka & $\begin{array}{l}\text { Ustanovení dle čtvrté } \\
\text { direktivy }\end{array}$ & $\begin{array}{l}\text { Současná situace v České } \\
\text { republice }\end{array}$ \\
\hline Součásti účetni závěrky & $\begin{array}{l}\text { Rozvaha, výsledovka, } \\
\text { komentár̆ }\end{array}$ & Rozvaha, výkaz zisku a ztráty \\
\hline $\begin{array}{l}\text { Položky v rozvaze - strana } \\
\text { aktiv }\end{array}$ & $\begin{array}{l}\text { A. Pohledávky za upsaný } \\
\text { nesplacený kapitál } \\
\text { B. Zřizovací výdaje } \\
\text { C. Dlouhodobá aktiva } \\
\text { D. Krátkodobá aktiva } \\
\text { E. Náklady a př́ijmy př́ǐstích } \\
\text { období } \\
\text { F. Ztráta za účetní období }\end{array}$ & $\begin{array}{l}\text { A. Pohledávky za upsaný } \\
\text { základní kapitál } \\
\text { B. Dlouhodobý majetek } \\
\text { C. Oběžná aktiva } \\
\text { D. Časové rozlišení }\end{array}$ \\
\hline $\begin{array}{l}\text { Položky v rozvaze - strana } \\
\text { pasiv }\end{array}$ & $\begin{array}{l}\text { A. Kapitál a rezervní fondy } \\
\text { B. Rezervy } \\
\text { C. Závazky } \\
\text { D. Výdaje a výnosy prríštích } \\
\text { období } \\
\text { E. Zisk za účetní období }\end{array}$ & $\begin{array}{l}\text { A. Vlastní kapitál } \\
\text { B. Cizí zdroje } \\
\text { C. Časové rozlišení }\end{array}$ \\
\hline
\end{tabular}

Pramen: ŠEBESTÍKOVÁ, V., KRAJŃÁK, M., IAS/IFRS jako nástroj harmonizace účetnictví nejen v EU, vlastni zpracování. 
Aktuální situace je v ČR víceméně v souladu s ustanoveními čtvrté direktivy. Direktiva zároveň dovoluje položku $\mathrm{F}$ - Ztráta za účetní období v rozvaze na straně aktiv zahrnout na stranu pasiv v položce A - Kapitál a rezervní fondy. Této alternativy využívá i české účetnictví.

\section{Závěr}

Uvedený příspěvek se zabýval sestavováním rozvahy jako základního účetního výkazu dle požadavků IAS/IFRS. Tyto standardy jsou pro Evropu a tím i Českou republiku vhodnější ve srovnání s účetními standardy USA - US GAAP, které byly vytvořeny a priori pro potřeby států v Americe.

Jak již bylo řečeno výše, zásadním problémem v mnohých zemích včetně ČR je vazba účetních a daňových předpisů. IFRS jsou vždy zaměřeny na řešení podstaty problému z věcné stránky, nikoliv z pohledu daňového.

Čtvrtá direktiva EU dovádí požadavky na účetní výkazy až do formalizované podoby a předkládá $\mathrm{k}$ výběru dva vzory rozvahy, a to $\mathrm{v}$ podrobné struktuře.Naproti tomu IFRS své požadavky nezařazují do žádného standardizovaného formátu. Ponechávají na podniku, aby sám zvolil tu nejvhodnější formu s cílem zajistit externím uživatelům takový rozsah informací a v takové formě, aby si mohli učinit správný názor na finanční pozici, výkonnost a peněžní toky podniku.

Teoretické poznatky, prezentované $\mathrm{v}$ prríspěvku, bych chtěla dále rozvinout $\mathrm{v}$ rámci svého vědeckého výzkumu, ve kterém se věnuji zpracování a vyhodnocení dat pro sestavení konsolidované účetní závěrky u vybraných účetních jednotek. Domnívám se, že zde musí účetní jednotky zvážit, zda náklady na zpracování účetnictví podle IFRS na jedné straně a tvorba podkladů pro daň z př́jmů, kdy základ daně i nadále vychází z výsledku hospodaření zjištěného podle českých účetních předpisů, vyváží přínosy ze zjednodušené komunikace $\mathrm{v}$ rámci konsolidačního celku.

Můj názor na uvedenou problematiku vychází z toho, že je nutné pokračovat v budování jednotného systému účetnictví uznávaného na celém světě. K dosažení toho je nutné, aby informace prezentované $\mathrm{v}$ účetních výkazech byly relevantní a důvěryhodné a aby bylo možno se na ně spolehnout. $\mathrm{K}$ tomu v současné době významnou měrou přispívá projekt konvergence Koncepčních rámců IAS/IFRS. Bylo by žádoucí, aby se do úsilí o konvergenci zapojili i národní regulátoři finančního účetnictví, kteří tak budou informováni o aktuálním světovém vývoji a mohou se jím inspirovat při tvorbě národní účetní legislativy. Považuji proto za významné vytvoření koncepčního rámce v ČÚL.

V závěru bych se zmínila o legislativních změnách v zákoně o účetnictví po 1.1.2011, které se týkají použití IFRS při sestavení účetní závěrky, kde v novém $\S 22$ dochází ke zpřesnění definice pojmů konsolidující a konsolidovaná účetní jednotka.

Ve snaze přiblížit účetní výkazy, sestavené dle IFRS, s účetními výkazy sestavenými pro daňové účely, Evropská komise zveřejnila dne 16.března 2011 návrh nové směrnice o společném konsolidovaném základu daně z př́ijmů právnických osob. 


\section{Literatura:}

[1] DVOŘÁKOVÁ, D., Finanční účetnictví a výkaznictví podle mezinárodních standardi̊ IAS/IFRS. 1.vyd. Brno: ComputerPress, 2006, 339 s. ISBN 80251-1085-0.

[2] KOVANICOVÁ, D., Finanční účetnictví - světový koncept IFRS/IAS . 5.vyd. Praha: Polygon, 2005, 132 s. ISBN 80-7273-129-7.

[3] KRUPOVÁ, L., VAŠEK, L., ČERNÝ, M., IAS/IFRS Mezinárodní standardy účetního výkaznictví. 1.vyd .Praha:Vox, 2005, 1050 s. ISBN 80863224-44-3.

[4] ŠEBESTÍKOVÁ, V., KRAJŃÁK, M., IAS jako nástroj harmonizace účetnictví nejen v $E U .1$. vyd. SU Karviná: Sborník příspěvků I.mezinárodní vědecké konference Aktuální trendy pro rozvoj ekonomiky, 2010626 s. ISBN 978-80-7248-631-1.

[5] Zákon č.563/1991 Sb., o účetnictví ve znění platných předpisů

[6] Vyhláška č.500/2002 Sb., kterou se provádějí některá ustanovení zákona č.563/1991Sb., o účetnictví ve znění platných předpisů pro účetní jednotky, které jsou podnikateli účtujícími v soustavě podvojného účetnictví

[7] http://circa.europa.eu/Public/irc/markt/markt_consultations/library?l=/accounting/consoli dated_17102008/ifrs_consolidated_2/_CS_1.0_\&a=d

[8] http://en.wikipedia.org/wiki/International_Financial_Reporting_Standards

\section{Klasifikace JEL: E41 E42}

\section{Ing. Dagmar Čespivová}

Finanční úřad v Karviné

Fryštátská 89

73301 Karviná- Fryštát

Dagmar.Cespivova@kar.os.ds.mfcr.cz 